Abstracta Iranica Abstracta Iranica

Revue bibliographique pour le domaine irano-aryen

Volume 31 | 2011

Comptes rendus des publications de 2008

\title{
Bayān al-Haqā’iq. Hāšem Rajabzāde, éd., Tehrān, Mīrāt-e Maktūb, 1386/2008, 406 + xliii p., index.
}

\section{Fabrizio Speziale}

\section{(2) OpenEdition}

1 Journals

\section{Édition électronique}

URL : http://journals.openedition.org/abstractairanica/39705

DOI : 10.4000/abstractairanica.39705

ISSN : 1961-960X

Éditeur :

CNRS (UMR 7528 Mondes iraniens et indiens), Éditions de l'IFRI

\section{Édition imprimée}

Date de publication : 15 mai 2011

ISSN : 0240-8910

\section{Référence électronique}

Fabrizio Speziale, « Bayān al-Haqā̄iq. Hāšem Rajabzāde, éd., Tehrān, Mīrāte-e Maktūb, 1386/2008, 406 + xliii p., index. », Abstracta Iranica [En ligne], Volume 31 | 2011, document 235, mis en ligne le 11 octobre 2012, consulté le 05 octobre 2020. URL : http://journals.openedition.org/abstractairanica/39705 DOI : https://doi.org/10.4000/abstractairanica.39705

Ce document a été généré automatiquement le 5 octobre 2020.

Tous droits réservés 


\section{Bayān al-Haqū’iq. Hāšem Rajabzāde, éd., Tehrān, Mīrāt-e Maktūb, 1386/2008, $406+$ xliii p., index.}

Fabrizio Speziale

Le Bayān al-Haqā’iq est un recueil de dix-sept traités (rasā’il) par Rašīd al-Dīn Faḍl Allāh Hamadānī (m. 718/1318), le célèbre homme d'État et historien de la période ilkhanide. Les rasā'il qui composent cet ouvrage concernent surtout l'exégèse coranique et des questions de théologie et de philosophie, et certains de ces traités se retrouvent également dans un autre recueil de textes de Hamadānī, intitulé As'ale va ajvabe. Cette édition est basée sur deux copies de l'ouvrage, une en langue persane, dont le manuscrit est conservé à la Bibliothèque Majles de Téhéran, et l'autre en arabe, conservé à la Bibliothèque Suleymaniye d'Istanbul.

Hāšem Rajabzāde

\section{INDEX}

Thèmes : 7. Islam

\section{AUTEURS}

\section{FABRIZIO SPEZIALE}

Université Sorbonne Nouvelle - Paris 3 - Mondes iranien et indien 